\title{
Section XI: Destruction of Property
}

\author{
Rule 97 \\ It is specifically prohibited to destroy, damage or seize enemy private or \\ public property unless such destruction is justified by military necessity \\ under the principles and rules of LOAC.
}

\section{Commentary}

1. This Rule is based on Article 23(g) of the 1907 Hague Regulations and the customary international law of armed conflict. ${ }^{1}$ The Rule is, in principle, applicable to all domains of warfare (air, sea, land, cyber and space).

2. Military necessity includes those measures imperatively required in order to achieve the aims or ends of warfare, and (hereunder) having a reasonable connection to those ends. Military necessity must be distinguished from political, economic or diplomatic needs.

3. Destruction of property qualifying as military objectives is a fortiori also necessary, and lawful. The practical scope of the Rule thus relates to enemy civilian property during international armed conflict.

4. The notion of property is not defined by applicable treaties. The notion of property must therefore be understood in light of its ordinary (dictionary) meaning. All tangible, movable or immovable items as well as real property fall within the notion of "property".

\footnotetext{
${ }^{1}$ The rule appeared at the Brussels Conference (1874), The Laws of Armed Conflicts, page 21, Article 13(g). Today, its customary status is expressed for example in Henckaerts and Doswald-Beck, International Committee of the Red Cross Customary International Humanitarian Law (CIHL), (Cambridge: Cambridge University Press) (2005, reprint 2009), vol. I, rule 50, and the Rome Statute of the International Criminal Court (Rome Statute) (1998), The Laws of Armed Conflicts, page 1309, Article 8(2)(b)(xiii).
} 
5. There is an increasing legal debate as to whether intangible objects are to be considered property. The Group of Experts did not reject the possibility that, for example, data can qualify as "property" under LOAC. On the other hand, the majority of the Group was of the opinion that intellectual property does not qualify as "property" under LOAC.

6. Necessary destruction, damage or seizure of property may be connected to an attack, but it may also result incidentally from sheer movements and manoeuvers of armed forces. By way of example, buildings, roads, bridges, fences and cultivated fields may be destroyed or damaged as a result of the weight and speed of military vehicles (such as tanks).

7. Military necessity may require and thus justify the destruction, damage or seizure of enemy property in the course of or in preparation for an attack (as defined in LOAC) or other military operations.

8. Destruction, damage or seizure of enemy property may occur in a manner that is incidental to movement and manoeuver of troops. Such destruction, damage or seizure may be considered as an unavoidable consequence of warfare and is thus justified on the basis of military necessary.

9. Military necessity must be assessed by the commander based on the facts reasonably available to him/her under the circumstances prevailing at the time.

10. The present Rule applies without prejudice to rules governing special protection from attack, such as the rules providing protection of cultural property (see chapter "Section XV: Cultural Property") ${ }^{2}$ and medical facilities. ${ }^{3}$

11. The present Rule is without prejudice to the rules governing destruction, seizure and confiscation in the context of belligerent occupation.

12. In non-international armed conflict, the issue of what property is regarded as enemy property is more complex than in international armed conflicts, inasmuch as the State may seize, destroy or damage property under its jurisdiction in conformity with its domestic law.

\section{Rule 98 \\ In an international armed conflict, any extensive destruction or seizure of property, not justified by military necessity and carried out unlawfully and wantonly constitutes a war crime.}

\footnotetext{
${ }^{2}$ AP/I, see chapter "Section I: Outer Space" I, fn. 13, Article 53, Convention for the Protection of Cultural Property in the Event of Armed Conflict (1954), The Laws of Armed Conflicts, page 747, Article 4. Second Protocol to the Hague Convention of 1954 for the Protection of Cultural Property in the Event of Armed Conflict (1999), The Laws of Armed Conflicts, page 1037, Article 6. See also Rule 98 and chapter "Section XIV: Humanitarian Assistance" of this Manual.

${ }^{3}$ AP/I, ibid, Article 12, and GC/I, see chapter "Section I: Outer Space", fn. 19, Article 19. AMW Manual, see chapter "Section I: Outer Space", fn. 1, Section L. San Remo Manual, see chapter "Section I: Outer Space", fn. 29, para 169-183.
} 


\section{Commentary}

1. The present Rule is based on the language of Article 147 of GC/IV, which of course uses the language of "grave breach" of the Geneva Convention now understood to mean war crime (cf. Article 8 of the Rome Statute of the International Criminal Court).

2. The Rule is, in principle, applicable to all domains of warfare (air, sea, land, cyber and outer space). ${ }^{4}$

3. For all practical purposes, wantonness is the opposite of necessity (see Rule 97). ${ }^{5}$ Wanton destruction is particularly egregious destruction of property that is not motivated by lawful aims of warfare, but is random conduct or conduct motivated by a desire to inflict destruction as an end in itself. ${ }^{6}$ In order to qualify as a war crime the destruction or seizure of property must also be unlawful and extensive. An example of such wanton destruction is the burning of Kuwaiti oil wells by the retreating Iraqi forces in 1991 that was carried out without military necessity.

4. Destruction of property qualifying as a military objective is never considered wanton. Destruction of enemy property justified by military necessity in accordance with Rule 97 is never wanton.

5. The prohibition applies regardless of whether the property is State owned or owned by private persons or legal entities.

6. Destruction of property is generally accompanied by the counterpart term, damage (see Rule 97). The term damage does not appear in the present Rule because it is not mentioned in the text of Article 147 of GC/IV.

7. The term seizure is used in this Rule as a corollary of Rule 97. It encapsulates the notion of appropriation of property mentioned in Article 147 of GC/IV.

8. The present Rule is without prejudice to the rules governing destruction, seizure and confiscation in the context of belligerent occupation.

\section{Rule 99}

(a) It is prohibited to attack, destroy, remove or render useless objects indispensable to the survival of the civilian population for the specific purpose of denying them for their sustenance value to the civilian population or to the adverse Party, whatever the motive, whether in order to starve out civilians, to cause them to move away, or for any other motive.

\section{Commentary}

1. This Rule is based on Articles 54(2) of AP/I and 14 of AP/II.

\footnotetext{
${ }^{4}$ See Rule 97 with regard to the scope of application.

${ }^{5}$ As already expressed in the Lieber Code.

${ }^{6}$ In re List and Others (Hostages Trial), United States Military Tribunal at Nuremberg, in Annual Digest and Reports of Public International Law Cases (1948), at page 647.
} 
2. Under AP/I, exceptions exist for this Rule, such as for objects used by an adverse party "as sustenance solely for the members its armed forces" or "if not sustenance, then in direct support of military action". However, actions against this latter category of objects forfeiting protection may not be taken if they "may be expected to leave the civilian population with such inadequate food or water as to cause its starvation or force its movement".

3. Customary international law prohibits the starvation of civilians as a method of warfare.

(b) In recognition of the vital requirements of any Party to the conflict in the defence of its national territory against invasion, derogation from the prohibition in subparagraph (a) may be made by a Party to the conflict within such territory under its own control where required by imperative military necessity.

\section{Commentary}

1. This Rule is based on Article 54(5) of AP/I.

2. The Rule applies to the defence of a Belligerent State's own territory against an invading enemy force. That is to say the tactics of "scorched earth" cannot be used by the invading enemy, nor can such tactics be used by a State not taking action in the defence of its own territory.

Rule 100

Rules 97 and 98 are without prejudice to specific rules on capture as booty of war or as prize.

\section{Commentary}

1. Capture of property as booty of war or for prize is governed by specific rules. ${ }^{7}$ When capture or destruction is lawful according to these specific rules, the acts are also ipso facto required by military necessity and will not amount to acts of wantonness.

\section{Rule 101}

In a non-international armed conflict, destruction or seizure is not prohibited when directed against items illegally appropriated or produced (such as oil or opium) by non-State armed groups and used by them to generate revenue for the purpose of continuing the hostilities.

\footnotetext{
${ }^{7}$ Capture of war booty is a recognized lawful practice in customary international law, see CIHL, Rule 49, see fn. 1. Capture for prize at sea is dealt with in the San Remo Manual, see chapter "Section I: Outer Space", fn. 29, para 135-158, and in the AMW Manual, see chapter "Section I: Outer Space", fn. 1, Section U.
} 


\section{Commentary}

1. The Group of Experts was aware of the fact that this Rule is not accepted by all States. However, the majority of the Group believed that there is sufficient practice of States (as manifested in Syria since 2015) to substantiate the text.

2. Nevertheless, the majority of the Group of Experts could not agree on the conceptual underpinning for this new Rule. Different views were put forward with the view to providing a proper rationale.

3. One view, based on a wider-largely US - perception of LOAC, is that lawful targets of attack (and a fortiori property that it is lawful to destroy or seize, see paragraph 3 of the Commentary to Rule 97) include not only "war-fighting" or "war-supporting" but also "war-sustaining" enemy objects that qualify as military objectives. ${ }^{8}$

4. Another view, is that there is a sui generis rule relating to action against fleets of oil-tanker trucks (irrespective of their destination).

5. A third view is that this is a land alternative to naval or aerial blockade. Ordinarily, exports can be barred only through the imposition of a blockade. Yet, blockade as a method of warfare is irrelevant to (i) land-locked enemy countries in an international armed conflict, or (ii) any insurgent-held areas in a non-international armed conflict (since the construct of neutrality is alien to non-international armed conflicts). Absent the possibility of blockade, it has been argued that enemy exports can be barred through attacks against truck convoys.

6. Finally, there was a minority of the Group of Experts that acknowledged that the conduct described in this Rule would not qualify as a war crime, but that took the view that it would still be in violation of the law of non-international armed conflict.

7. In any event, destruction and seizure of items that are illegally (according to domestic law) appropriated or produced by non-State actors, is lawful according to the domestic law of most States.

Open Access This chapter is licensed under the terms of the Creative Commons Attribution 4.0 International License (http://creativecommons.org/licenses/by/4.0/), which permits use, sharing, adaptation, distribution and reproduction in any medium or format, as long as you give appropriate credit to the original author(s) and the source, provide a link to the Creative Commons licence and indicate if changes were made.

The images or other third party material in this chapter are included in the chapter's Creative Commons licence, unless indicated otherwise in a credit line to the material. If material is not included in the chapter's Creative Commons licence and your intended use is not permitted by statutory regulation or exceeds the permitted use, you will need to obtain permission directly from the copyright holder.

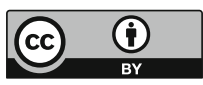

\footnotetext{
${ }^{8}$ See US DoD Manual, see chapter “Section II: Cyber Operations”, fn. 4, at page 237-238.
} 